\title{
Pull-Through in Patients after Pelvic Anastomosis Leak Following Proctectomy: A Cross-Sectional Study
}

\section{Abaixamento em pacientes após vazamento de anastomose pélvica após proctectomia: Um estudo transversal}

\author{
Hasan Davoodabadi ${ }^{1}$ Mohammad Aldraji ${ }^{2} \quad$ Abdolhosein Davoodabadi Farahani $^{3}$ Parnian Soltani ${ }^{4}$ \\ Mehdi Alemrajabi ${ }^{1}$
}

${ }^{1}$ Firoozgar Hospital, Iran University of Medical Sciences, Tehran, Iran

2 Shahed Universtiy, Tehran, Iran

${ }^{3}$ Kashan University of Medical Sciences, Kashan, Iran

${ }^{4}$ Iran University of Medical Sciences, Tehran, Iran

Address for correspondence Mehdi Alemrajabi, Colorectal Surgeon, Firoozgar hospital, Iran University of Medical Sciences, Tehran, Iran (e-mail: alemrajabi.m@iums.ac.ir).

J Coloproctol 2021;41(1):42-46.

\begin{abstract}
Introduction Colorectal cancer is the second most common type of cancer and the third leading cause of mortality due to cancers. Anastomosis leak after proctectomy is a dangerous complication that must be managed carefully. The aim of the present study was to assess the procedure of resection and pull-through of the new rectum after anastomosis leak in patients after proctectomy.

Methods and Materials This was a cross-sectional study. Patients who visited the Firoozgar Hospital between 2015 and 2018 for rectal cancer surgery and had anastomosis leak entered the study. All patients underwent resection of the residue of rectum and pull-through of colon.

Results In the present study, out of the 110 cases who underwent proctectomy, 12 patients with postoperative anastomosis leak were reported. Five $(41.7 \%)$ were male and 7 (58.3\%) were female. The mean age of the patients was $41.5 \pm 4.3$ years (33-51). Resection of the new rectum and pull-through anastomosis were performed for these 12 patients. No major intraoperative complication occurred. Postoperative course was uneventful in all patients.

Discussion Resection of residue of rectum and pull-through in patients with anasto-

\section{Keywords}

- rectal cancer

- anastomosis leak

- proctectomy mosis leak can be done after rectal cancer surgery. This method is superior to abdominopelvic resection in many aspects, especially regarding accessibility to the new rectum by rectal exam or endosonography to assess recurrence or a relative continence after closure of ostomy.
\end{abstract}

received

July 5,2020

accepted

August 30, 2020
DOI https://doi.org/

$10.1055 / \mathrm{s}-0041-1724058$. ISSN 2237-9363. (c) 2021. Sociedade Brasileira de Coloproctologia. All rights reserved.

This is an open access article published by Thieme under the terms of the Creative Commons Attribution-NonDerivative-NonCommercial-License, permitting copying and reproduction so long as the original work is given appropriate credit. Contents may not be used for commercial purposes, or adapted, remixed, transformed or built upon. (https://creativecommons.org/ licenses/by-nc-nd/4.0/)

Thieme Revinter Publicações Ltda., Rua do Matoso 170, Rio de Janeiro, RJ, CEP 20270-135, Brazil 


\section{Resumo}

\section{Palavras-chave}

- câncer retal

- vazamento de anastomose

- protectomia
Introdução O câncer colorretal é o segundo tipo de câncer mais comum, e a terceira principal causa de mortalidade por câncer. O vazamento da anastomose após a proctectomia é uma complicação perigosa, que deve ser tratada com cuidado. $\mathrm{O}$ objetivo do presente estudo foi avaliar o procedimento de ressecção e abaixamento do novo reto após vazamento de anastomose em pacientes submetidos à proctectomia. Métodos e Materiais Este foi um estudo transversal que incluiu pacientes que compareceram ao Firoozgar Hospital entre 2015 e 2018 submetidos a cirurgia de câncer retal e com vazamento de anastomose. Todos os pacientes foram submetidos a ressecção do resíduo do reto e abaixamento do cólon.

Resultados No presente estudo, dos 110 casos submetidos a proctectomia, 12 pacientes tiveram vazamento de anastomose pós-operatório: 5 (41,7\%) do sexo masculino e 7 (58,3\%) do sexo feminino. A idade média dos pacientes foi de 41,5 \pm 4,3 anos (gama: 33 a 51 anos). A ressecção do reto novo e a anastomose por abaixamento foram realizadas nesses 12 pacientes. Nenhuma complicação intraoperatória mais grave ocorreu. No pós-operatório, não houve intercorrências em nenhum dos pacientes.

Discussão A ressecção de resíduo retal e o abaixamento em pacientes com vazamento de anastomose pode ser feita após cirurgia de câncer retal. Este método é superior à ressecção abdominopélvica em muitos aspectos, especialmente quanto à acessibilidade ao novo reto por exame retal ou endossonografia para avaliar a recorrência ou uma continência relativa após o fechamento da ostomia.

\section{Introduction}

Colorectal cancer is the second most common type of cancer and the third leading cause of death from cancers in the world. In 2012, 1,360,602 new cases of colorectal cancers have been identified. Its mortality rate in 2008 was estimated as 48 in 100,000 . Colorectal cancer is associated with advanced age, so that at least $50 \%$ of the individuals in western societies up to the age of 70 have a variety of colorectal problems, including a range of benign polyps and malignant adenocarcinomas. ${ }^{1-3}$

Proctectomy via laparoscopy or open approach is widely performed in many medical centers. However, it is associated with some complications intra or postoperatively.

Anastomosis leak can be clinically diagnosed between 5 and 8 days after the operation. ${ }^{4}$ Anastomosis leak presents differently. It can manifest as a generalized peritonitis requiring re-operation, or localized accumulation of fluid that can be drained by radiology. Anastomosis leak requires numerous radiological evaluations, long-term admission into hospital, and increased morbidity and mortality. ${ }^{5}$

The incidence of colorectal anastomosis stenosis leak varies from 3 to $30 \%$. Most of these stenoses are simple narrowing of the lumen that can be treated with dilation; however, up to $28 \%$ of patients need resurgical repairs. The presence of ileostomy cannot affect the rate of anastomosis leakage but reduces the complications to some extent. ${ }^{6-9}$ Another complication of rectal anastomosis is fecal incontinence, ${ }^{10}$ which is associated with disability, reduced quality of life, and high cost of treatment. In many of these patients, diverting ostomy is needed until the end of life. Many surgeons also recommend abdominoperineal resection and end colostomy for such patients.

A systematic review of the World Journal of Gastrointestinal Surgery in 2015 examined the risk factors and treatment of colorectal anastomosis. A Hartmann procedure was performed in case of wide detachment and necrosis of the anastomosis site. On the other hand, in patients with better general condition, some endoscopic methods such as sponge, stent, and clips have been studied. ${ }^{11}$ Hartmann's technique has been approved widely in patients with a major anastomosis detachment and pelvic necrosis.

In another study, conducted in 2007, 1,421 patients with pelvic floor anastomosis were studied, 41 of whom, including 25 men and 16 women, presented with symptoms of anastomosis leak. They were treated with 3 methods of surgical procedures, antibiotic therapy, and radiological drainage. ${ }^{12}$ The median time for diagnosis of anastomosis leak was $\sim 7$ days. Twenty-one patients underwent resurgical operation, and a permanent ostomy was considered. Despite this, colon resection and pullthrough in anastomosis leak after proctectomy is a choice that is superior to other approaches in some respects. In patients who undergo abdominoperineal resection (APR) for rectal cancer, recurrence of a pelvic mass could be a disaster. However, if the GI continuity is preserved, recurrence might be diagnosed faster by rectorrhagia or obstruction in earlier stages.

Therefore, the aim of the present study was to assess the results of colon resection and pull-through in anastomosis leak after proctectomy and compare the results with those of other approaches in the literature. 


\section{Methods and Materials}

\section{Patients and Method}

This was a cross-sectional study of 12 patients with postoperative anastomosis leak after rectal cancer surgery referred to the Firoozgar Hospital of Teheran between 2015 and 2018. All patients underwent resection of the residue of rectum and pull-through of rectum. All patients with rectal cancer who underwent either open or laparoscopic proctectomy due to rectal cancer and were admitted due to anastomosis leak were included in the study. The exclusion criteria included those patients with obstructive rectal cancer in whom curative treatment could not be performed; patients with other non-rectal cancers; those with solitary rectal ulcer, familial adenomatous polyposis (FAP), or other entities which were treated by performing a proctectomy; and patients with anastomosis leak presenting with a generalized peritonitis with the need of urgent laparotomy or those with unstable hemodynamic status who could not tolerate conservative treatment of anastomosis leak. An informed consent was obtained from each patient before recruitment in the study, and they were ensured of the confidentiality of their information. The protocol of the study was approved by the Research Ethics Committee of the Iran university of medical science. All steps of the study were in accordance with the guidelines of the Helsinki Declaration. The patients were free to drop out of the study at any stage without affecting their standard process of treatment.

\section{Surgical Technique}

After placing the patient in a semi-lithotomy position, the residue of rectum was resected and pull-through was performed. Subsequently, using a Lone Star retractor in full lithotomy, the colon was withdrawn from the anus and coloanal anastomosis was performed. The amount of bleeding during the operation, the need for intraoperative blood transfusion, and the duration of the operation were recorded by the surgeon in the checklist.

The patients were discharged from the hospital after recovery. Their ileostomy was re-closed after examination with contrast agent after 2 to 3 months. Then, the complete results of the patients' surgery and the number of hospital days and possible postoperative complications and fecal incontinence score using the Jorge-Wexner questionnaire were collected and evaluated. The patients' quality of life was also evaluated using the 36-Item Short Form Health Survey (SF-36) questionnaire. Finally, the information obtained from the checklists, intraoperative findings, and the final result, including existence or absence of anastomosis, were analyzed by the SPSS software version 16 (SPSS Inc., Chicago, Il, USA).

\section{Results}

In the present study, of the 110 cases who underwent proctectomy, 13 cases of postoperative anastomosis leak were reported (11.81\%). Of these 13 patients, one refused to participate in the study. Therefore, 12 patients were enrolled in the study. Of these 12 patients, 7 came from our center and 5 were referred from other surgeons. Five (41.7\%) were male and 7 (58.3\%) were female. The mean age of the patients was 41.5 years (33-51). All patients had undergone chemo-radiotherapy prior to their first operation (proctectomy), and the most recent operation was postponed after completion of their chemotherapy course to exclude the probability of metastasis to other organs by imaging. During this period, the ileostomy was not closed. Three patients (25\%) were smokers and none of the patients used steroids or alcohol.

All of these 12 patients were operated using the laparoscopic approach. Red blood cell transfusion was not required for any patient during the operation. The mean albumin level of the patients before the operation was $3.9 \mathrm{~g} / \mathrm{dl}$ (3.7-4.375). The mean amount of bleeding during the operation was $30 \mathrm{ml}$. The median time of rectum resection and pullthrough operation was 155 (120-180) minutes. The mean days of hospitalization in our study was 27 (14-40) days, which consisted of 3 courses-the first one when the patient underwent primary proctectomy, the second one was when the patient admitted to our center with the diagnosis of anastomosis leak and medical therapy was performed, and the third one was when the patient underwent the operation as resection of the new rectum and pull through. A summary of the demographic and intraoperative characteristics of the participants is presented in - Table 1 .

The mean score of fecal incontinence after resection of rectum and pull-through was $12.8 \pm 7.25$. None of the patients had any postoperative complications such as stenosis or detachment of the new colon-anal anastomosis. The mean score in each of the 8 subcategories of the SF-36 questionnaire is shown in - Table 2 .

Table 1 A Summary of demographic and intraoperative characteristics of the participants

\begin{tabular}{|l|l|}
\hline Variable & Value \\
\hline Gender & $5(41.7 \%)$ \\
\hline Male & $7(58.3 \%)$ \\
\hline Female & $41.5 \pm 4.3$ \\
\hline Age (years) (mean \pm SD) & $3.9 \pm 0.8$ \\
\hline $\begin{array}{l}\text { Preoperative albumin } \\
\text { level (g/dl) }\end{array}$ & $30 \pm 4.6$ \\
\hline $\begin{array}{l}\text { Intra-operative bleeding } \\
\text { (mL) (mean } \pm \text { SD) }\end{array}$ & $155(120-180)$ minutes \\
\hline $\begin{array}{l}\text { Operation time (minutes) } \\
\text { (median; range) }\end{array}$ & $27(14-40)$ \\
\hline $\begin{array}{l}\text { Hospitalization (days) } \\
\text { (median; range) }\end{array}$ & $12.8 \pm 7.25$ \\
\hline $\begin{array}{l}\text { Jorge-Wexner score } \\
\text { after the operation }\end{array}$ & \\
\hline
\end{tabular}

Abbreviation: SD, standard deviation.

*including primary proctectomy, admitting due to anastomosis leak and medical therapy, and the course of resection of the new rectum and pull-through.

**Wexner score after 2 months of resection of the new rectum and pullthrough. 
Table 2 Scores of quality of life for participants

\begin{tabular}{|l|l|}
\hline Variable & Value \\
\hline Vitality (mean \pm SD) & $60.0 \pm 33.22$ \\
\hline Physical functioning (mean \pm SD) & $56.0 \pm 45.01$ \\
\hline Body pain (mean \pm SD) & $40.0 \pm 41.16$ \\
\hline Health perception (mean \pm SD) & $46.66 \pm 42.16$ \\
\hline Physical role function (mean \pm SD) & $42.49 \pm 34.34$ \\
\hline Emotional role function (mean \pm SD) & $43.55 \pm 10.22$ \\
\hline Social role function (mean \pm SD) & $60.0 \pm 37.63$ \\
\hline Mental health (mean \pm SD) & $39.10 \pm 19.79$ \\
\hline
\end{tabular}

Abbreviation: SD, standard deviation.

\section{Discussion}

Regarding the high prevalence of colorectal cancer, the followup and treatment of these patients are important. Intersphincteric resection (ISR) is one of the accepted methods for distal rectal cancer, and it is performed by laparoscopic approach. ${ }^{13,14}$ Possible complications include leakage of anastomosis and stenosis, which will increase the mortality rate and hospitalization stay. Different treatments have been proposed from drainage to resurgical procedures. ${ }^{15,16}$

In the study by Braun et al., in 1992, the results of the APR and ISR surgery were compared (63 ISR patients and 77 APR patients). Among patients undergoing ISR curative surgery, $11 \%$ had pelvic recurrence and $33 \%$ had distant metastasis, and among patients with APR, $17 \%$ had pelvic recurrence and $35 \%$ had distant metastases. The 5-year survival rate in patients with ISR and APR were $62 \%$ and 53\%, respectively. Overall, $85 \%$ of patients had a good function. The study found that ISR is a valuable method for middle and high-grade neoplasms, which allows a minimum of $3 \mathrm{~cm}$ distal margin. ${ }^{17}$

In another study by Nachiappan et al. in 2014, 1,048 patients who underwent different kinds of colectomy were examined. Generally, 99 patients developed anastomosis leak $(9.4 \%)$, which is quite similar to the rate reported in our study. Of 99 patients, 56 underwent reoperation and 43 managed with antibiotics or radiological drainage. They finally concluded that patients with anastomotic leaks who require reoperations have shorter overall survival than those without leak, but disease-free survival was not significantly different between the two groups. ${ }^{18}$

Another large study assessed 72,055 patients with rectal cancer who underwent elective anterior resection. They tried to build a predictive model for anastomosis leak using demographic characteristics and preadmission comorbidities. was According to their study, the probability of anastomosis leak was $13.68 \%$, which is higher than the rate found in our patients. Mortality rate, hospital stay, and expenses were significantly higher in patients in whom anastomosis leak occurred. They found that weight loss and malnutrition, electrolyte imbalance, male gender, and stoma placement were risk factors for anastomosis leak. They also found that laparoscopy approach for proctectomy decreased the risk of anastomosis leak. ${ }^{19}$
In the present study, resection of rectum residue and pullthrough were assessed. Also, the literature was searched regarding detachment of the anastomosis and a permanent end colostomy. In the current study, all patients with anastomosis leak after rectal cancer surgery entered the study. Twelve patients were eventually examined (mean age of 41.5 years). In general, $25 \%$ of our patients were smokers; however, there was no statistically significant effect for smoking on hospitalization stay, incontinency score, or SF-36 score.

In this study, we assessed incontinency using the JorgeWexner questionnaire. The mean incontinency score in our study was 12.8 , which is superior to end-colostomy naturally.

However, the quality of life of these patients was assessed using the SF-36 questionnaire. Scores related to each of the areas of physical and mental health were calculated. In spite of the higher score of each of the two domains in our study, this difference was not statistically significant, which could be due to the small sample size in our study.

In general, anastomosis leak after proctectomy can be easily managed by resection of rectum and pull-through and a protective loop ileostomy. It is a safe method, which is superior to APR in some aspects. For instance, the new rectum is accessible to evaluate possible recurrence via rectal examination or endosonography, but it cannot be done in APR. However, The GI continuity is preserved, and, if the new anastomosis functions well, loop ileostomy can be further closed, and a relative fecal continence is attained.

It should be noted that only stable patients with anastomosis leak entered our study. Those patients who needed laparotomy due to peritonitis and those with unstable hemodynamic status who transferred to the operation room after the first admission were excluded. Despite this, the rate of anastomosis leak in our study included those patients who were referred to our center from other surgeons, as our hospital is a center for colorectal diseases. Therefore, our actual rate of anastomosis leak could be very lower if only our patients were considered. Further studies with larger sample sizes and longer follow-ups are recommended to compare the outcome of resection and pullthrough with APR.

\section{Authors' Contribution}

All the authors contributed equally in the preparation of the present manuscript.

Conflict of Interests

The authors have no conflict of interests to declare.

\section{References}

1 Ferlay J, Shin H, Bray F, Forman D, Mathers C, Parkin DGLOBOCAN 2008 v1. 2, Cancer Incidence and Mortality Worldwide: IARC CancerBase No. 10. Lyon: International Agency for Research on Cancer; 2011. globocan iarc f r (accessed March 28, 2013).2012

2 Miles WE. A method of performing abdomino-perineal excision for carcinoma of the rectum and of the terminal portion of the pelvic colon. Lancet 1908;172(4451):1812-1813

3 Alemrajabi M, Bananzadeh A, Moradi M, Alemrajabi F, Vahdani M, Miri SR. A novelty in laparoscopic total colectomy with natural 
orifice specimen extraction using a plastic cover. J Coloproctol (Rio J) 2020

4 Hyman N, Manchester TL, Osler T, Burns B, Cataldo PA. Anastomotic leaks after intestinal anastomosis: it's later than you think. Ann Surg 2007;245(02):254-258

5 Thornton M, Joshi H, Vimalachandran C, et al. Management and outcome of colorectal anastomotic leaks. Int J Colorectal Dis 2011; 26(03):313-320

6 Weinstock LB, Shatz BA. Endoscopic abnormalities of the anastomosis following resection of colonic neoplasm. Gastrointest Endosc 1994;40(05):558-561

7 Di Giorgio P, De Luca L, Rivellini G, Sorrentino E, D’amore E, De Luca B. Endoscopic dilation of benign colorectal anastomotic stricture after low anterior resection: A prospective comparison study of two balloon types. Gastrointest Endosc 2004;60(03):347-350

8 Lin S-C, Sy E, Lin B-W, Lee J-C. Management of colorectal anastomotic strictures using multidiameter balloon dilation. J Soc Colon Rectal Surgeon (Taiwan) 2009;20(03):62-68

9 Johansson C. Endoscopic dilation of rectal strictures: a prospective study of 18 cases. Dis Colon Rectum 1996;39(04):423-428

10 Mileski WJ, Joehl RJ, Rege RV, Nahrwold DL. Treatment of anastomotic leakage following low anterior colon resection. Arch Surg 1988;123(08):968-971

11 Boccola MA, Buettner PG, Rozen WM, et al. Risk factors and outcomes for anastomotic leakage in colorectal surgery: a single-institution analysis of 1576 patients. World J Surg 2011;35(01):186-195

12 Kruschewski M, Rieger H, Pohlen U, Hotz HG, Buhr HJ. Risk factors for clinical anastomotic leakage and postoperative mortality in elective surgery for rectal cancer. Int J Colorectal Dis 2007;22(08): 919-927

13 Pavlidis TE, Pavlidis ET, Sakantamis AK. The role of intersphincteric resection in very low rectal cancer. Ann Surg Oncol 2017;24 (03, Suppl 3):612-613

14 Zhang X, Wu Q Hu T, Gu C, Bi L, Wang Z. Laparoscopic versus conventional open surgery in intersphincteric resection for low rectal cancer: A systematic review and meta-analysis. J Laparoendosc Adv Surg Tech A 2018;28(02):189-200

15 Mirnezami A, Mirnezami R, Chandrakumaran K, Sasapu K, Sagar P, Finan P. Increased local recurrence and reduced survival from colorectal cancer following anastomotic leak: systematic review and meta-analysis. Ann Surg 2011;253(05):890-899

16 McDermott FD, Heeney A, Kelly ME, Steele RJ, Carlson GL, Winter DC. Systematic review of preoperative, intraoperative and postoperative risk factors for colorectal anastomotic leaks. Br J Surg 2015;102(05):462-479

17 Braun J, Treutner KH, Winkeltau G, Heidenreich U, Lerch MM, Schumpelick V. Results of intersphincteric resection of the rectum with direct coloanal anastomosis for rectal carcinoma. Am J Surg 1992;163(04):407-412

18 Nachiappan S, Askari A, Malietzis G, et al. The impact of anastomotic leak and its treatment on cancer recurrence and survival following elective colorectal cancer resection. World J Surg 2015; 39(04):1052-1058

19 Kang CY, Halabi WJ, Chaudhry OO, et al. Risk factors for anastomotic leakage after anterior resection for rectal cancer. JAMA Surg 2013;148(01):65-71 